\title{
Welcome to the 83rd Annual Meeting of the American Thyroid Association
}

\author{
Ronald J. Koenig ${ }^{1}$ and Julie Ann Sosa ${ }^{2}$ \\ for the American Thyroid Association 2013 Annual Meeting Program Committee*
}

$\mathbf{W}$ E WOULD LIKE TO INVITE YOU to attend the 83rd Annual Meeting of the American Thyroid Association, held October 16-20, 2013, in beautiful and historic San Juan, Puerto Rico. We hope you will share the enthusiasm of the Program Committee regarding the exciting spectrum of topics and speakers.

The program features 2 plenary talks; 14 symposia; 15 Meet the Professor (MTP) workshops; lectures by the recipients of the Van Meter, Ingbar, Starr, and Braverman awards; the annual Clark Sawin Historical Vignette; and a Multidisciplinary Tumor Board session. In addition, nearly $300 \mathrm{ab}-$ stracts will be presented in oral or poster format by ATA members. The program sessions, a few of which will be highlighted here, address the latest advances and controversies.

Prior to the official start of the meeting, the ATA/AACE Advanced Endocrine Neck Ultrasound Course will occupy most of the day on October 16. The opening session that evening will review the most important developments over the past year in basic, clinical, and surgical thyroidology. The speakers for this Year in Review session will be recognized experts in those fields, Drs. Anthony Hollenberg, Megan Haymart, and David Steward.

Recent discoveries have resulted in the successful differentiation of mouse embryonic stem cells into functioning thyroid follicles that, when transplanted into an athyroid mouse, can restore euthyroidism (1). This stunning accomplishment, with important basic and clinical implications, will be presented in a plenary lecture by Dr. Sabine Costagliola. Dr. Arul Chinnaiyan, a leader in the discovery of cancer-driving gene mutations and the therapeutic applications of cancer genome sequencing (2), will present the second plenary lecture, Application of Integrative Sequencing for Precision Oncology.

The association between thyroid status and various global aspects of metabolism such as metabolic rate and lipid levels has been appreciated for decades. Recent advances in basic and translational research have provided surprising insights into the underlying mechanisms (3) and have greatly broadened our appreciation of the clinical importance of the thyroid in the regulation of metabolism (4-6). A MTP workshop with Drs. Kevin Phillips and Koshi Hashimoto will discuss Thyroid Hormone Regulation of Cholesterol and Liver Metabolism; and a basic symposium on Thyroid Hormone Control of Metabolism featuring Drs. Paul Yen, Miguel Lopez, and Pieter de Lange will present the latest data on the multiple ways thyroid hormones regulate energy metabolism, including important effects through liver autophagy and sirtuins, as well as through the regulation of central (hypothalamic) pathways.

The essential role of thyroid hormone in neurological development also has been appreciated for decades. The underlying mechanisms have been challenging to uncover. Yet, recent advances have not only provided important insights but have expanded our appreciation of the important roles that thyroid hormones play in diverse areas of neurobiology, including neural stem-cell commitment (7), hypothalamic regulation of cardiovascular function (8), and development of the visual and auditory systems (9). Drs. Barbara Demeneix, Björn Vennstrom, and Douglas Forrest will discuss these topics in a basic symposium on Thyroid Hormone and Neurobiology.

Cancer is one of the most heavily studied and rapidly advancing areas of thyroidology, in large part due to advances in our understanding of the molecular mechanisms of this disease and the development of targeted therapies. The 83rd Annual Meeting will provide numerous sessions to update attendees on the latest advances and to provide opportunities to discuss ongoing controversies. A symposium on the Molecular Underpinnings of Thyroid Cancer Development and Growth will integrate basic, clinical, and translational data to achieve a more comprehensive view of the topic. In fact, this type of integration is a theme that the Meeting embraces in numerous sessions. Dr. Thomas Giordano will present the highly anticipated data on papillary carcinomas from The

\footnotetext{
${ }^{1}$ Division of Metabolism, Endocrinology and Diabetes, University of Michigan Medical School, Ann Arbor, Michigan.

${ }^{2}$ Section of Endocrine Surgery, Department of Surgery, Duke University School of Medicine, Durham, North Carolina.

*American Thyroid Association 2013 Annual Meeting Program Committee: Ronald J. Koenig and Julie Ann Sosa, Co-Chairs; Sylvia L. Asa, Eren Berber, Naifa L. Busaidy, Anne R. Cappola, Frances E. Carr, Sheue-yann Cheng, John A. Copland III, Douglas B. Evans, Douglas Forrest, Emad Kandil, Brian W. Kim, Stephen H. LaFranchi; Michael T. McDermott, CME Program Director; Robert C. McIntyre Jr., Yuri Nikiforov, Sara I. Pai, Louis N. Pangaro, Elizabeth N. Pearce, Basil Rapoport, Honey V. Reddi, Yun-Bo Shi, Robert C. Smallridge, Theo J. Visser, Marilene B. Wang, Wilmar M. Wiersinga, Graham R. Williams, Mingzhao Xing; Bryan R. Haugen, ATA Board Liaison; Barbara R. Smith, Ex Officio; Adonia C. Coates, Staff Liaison.
} 
Cancer Genome Atlas (TCGA). Dr. Jaroslaw Jendrzejewski will discuss long noncoding RNAs, and Dr. Edna Kimura will discuss microRNAs in thyroid cancer. The day-to-day management of the indeterminate thyroid nodule has become an area of intense debate with regard to the relative risks and benefits of alternative strategies, including surveillance, diagnostic surgery, or now the development of molecular testing to either try to "rule in" or "rule out" the diagnosis of thyroid cancer $(10,11)$. A symposium on the Diagnostic Testing of Thyroid Nodules will include an overview of indeterminate cytology, a review of molecular markers of thyroid cancer, and a comparison of commercially available tests in the analysis of thyroid nodules, by Drs. Scott Boerner, Yuri Nikiforov, and Stefan Grebe respectively. This will be complemented by another symposium on Molecular Diagnostic Testing of Thyroid Nodules: Decision Making for the Clinician, where Dr. Ralph Tufano will review decision-making for the surgeon, and Drs. Susan Mandel and Bryan McIver will debate decision-making for the endocrinologist. Increasingly, molecular markers are serving as targets for small molecule therapies in and out of clinical trials for locally advanced and metastatic thyroid cancer $(12,13)$. There will be a symposium, Update on Novel Therapies for Thyroid Cancer: When to Start and What to Use, during which Drs. Marcia Brose and Matt Ringel will provide overviews of drugs approved, in trial, and in the pipeline for differentiated and medullary thyroid cancers respectively. Dr. Ann Gramza will present a series of clinical cases to allow the panelists to work through their strategies in management. Finally, there will be a surgical symposium centered on Ongoing Controversies in the Surgical Management of Thyroid Cancer, where Dr. Sara Pai will discuss prophylactic central neck dissection for papillary thyroid cancer, Dr. Brendan Stack indications for lateral neck dissection, and Dr. Libby Grubbs operative strategies for microcarcinomas.

The Arthur Bauman Clinical Symposium will include a multidisciplinary panel highlighting everyday ethical dilemmas for different specialists involved in thyroidology, including endocrinologists, surgeons, and oncologists.

The MTP workshops will provide forums to facilitate discussion and debate, in addition to the presentation of data. A few of the 15 MTP workshops will be highlighted here. It is now established that T4 and T3 enter cells via specific transporters such as MCT8 and Oatp1c1, and that mutations in thyroid hormone transporters can be disease-causing $(14,15)$. An MTP workshop led by Drs. W. Edward Visser and Heike Heuer will provide an update on this important field. The discovery that 3-iodothyronamine (T1AM), a previously unappreciated thyroid metabolite, can have dramatic biological effects was unexpected $(16,17)$. The physiological role of T1AM is still being unraveled, and an MTP session led by Drs. Thomas Scanlan and Riccardo Zucchi will provide the latest information. Recent advances in DNA sequencing and other molecular techniques have invigorated clinical research and are providing renewed impetus for the establishment of large biorepositories and electronic registries to integrate samples with clinical information, outcomes, and molecular characterizations. Drs. Robert Smallridge and Michael Roehrl will discuss their experiences in the establishment and maintenance of these critical services. Other MTP workshops will include faculty from different specialties and will highlight controversies in the management of thyroid lymphoma, poorly differentiated, and anaplastic thyroid cancers, thyroid cancer in children, thyroid cancer in pregnancy, and thyroid disease in the elderly, as well as congenital hypothyroidism, Graves' disease in adults and children, and Graves' ophthalmopathy.

Several popular traditions will continue this year. The Fellows Program will proceed in parallel with the scientific meeting and is open to trainees from both endocrinology and surgery. A practicum in clinical thyroidology, Weird Thyroid Function Tests: Their Interpretation and Management, will be directed by Drs. Jeffrey Garber and Marius Stan and include audience participation. Finally, the meeting will close on Sunday with a Thyroid Cancer Tumor Board that will include panelists from endocrinology, surgery, pathology, nuclear medicine, and oncology discussing challenging cases.

We look forward to five days of discussion and exchange of ideas among clinicians, researchers, educators, and trainees from around the world involved in the advancement of thyroidology and the care of patients with benign and malignant thyroid disease. Hopefully, there will be sun. There will definitely be debate, advancement of science, and most importantly, collegiality and friendship.

\section{References}

1. Antonica F, Kasprzyk DF, Opitz R, Iacovino M, Liao XH, Dumitrescu AM, Refetoff S, Peremans K, Manto M, Kyba M, Costagliola S 2012 Generation of functional thyroid from embryonic stem cells. Nature 491:66-71.

2. Robinson DR, Wu YM, Kalyana-Sundaram S, Cao X, Lonigro RJ, Sung YS, Chen CL, Zhang L, Wang R, Su F, Iyer MK, Roychowdhury S, Siddiqui J, Pienta KJ, Kunju LP, Talpaz M, Mosquera JM, Singer S, Schuetze SM, Antonescu CR, Chinnaiyan AM 2013 Identification of recurrent NAB2STAT6 gene fusions in solitary fibrous tumor by integrative sequencing. Nat Genet 45:180-185.

3. Lin JZ, Martagon AJ, Hsueh WA, Baxter JD, Gustafsson JA, Webb P, Phillips KJ 2012 Thyroid hormone receptor agonists reduce serum cholesterol independent of the LDL receptor. Endocrinology 153:6136-6144.

4. de Lange P, Cioffi F, Senese R, Moreno M, Lombardi A, Silvestri E, De Matteis R, Lionetti L, Mollica MP, Goglia F, Lanni A 2011 Nonthyrotoxic prevention of diet-induced insulin resistance by 3,5-diiodo-L-thyronine in rats. Diabetes 60:2730-2739.

5. Lopez M, Varela L, Vazquez MJ, Rodriguez-Cuenca S, Gonzalez CR, Velagapudi VR, Morgan DA, Schoenmakers E, Agassandian K, Lage R, Martinez de Morentin PB, Tovar S, Nogueiras R, Carling D, Lelliott C, Gallego R, Oresic M, Chatterjee K, Saha AK, Rahmouni K, Dieguez C, Vidal-Puig A 2010 Hypothalamic AMPK and fatty acid metabolism mediate thyroid regulation of energy balance. Nat Med 16: 1001-1008.

6. Sinha RA, You SH, Zhou J, Siddique MM, Bay BH, Zhu X, Privalsky ML, Cheng SY, Stevens RD, Summers SA, Newgard CB, Lazar MA, Yen PM 2012 Thyroid hormone stimulates hepatic lipid catabolism via activation of autophagy. I Clin Invest 122:2428-2438.

7. Lopez-Juarez A, Remaud S, Hassani Z, Jolivet P, Pierre Simons J, Sontag T, Yoshikawa K, Price J, Morvan-Dubois G, Demeneix BA 2012 Thyroid hormone signaling acts as a neurogenic switch by repressing Sox 2 in the adult neural stem cell niche. Cell Stem Cell 10:531-543.

8. Mittag J, Lyons DJ, Sallstrom J, Vujovic M, Dudazy-Gralla S, Warner A, Wallis K, Alkemade A, Nordstrom K, Monyer H, 
Broberger C, Arner A, Vennstrom B 2013 Thyroid hormone is required for hypothalamic neurons regulating cardiovascular functions. J Clin Invest 123:509-516.

9. Ng L, Kelley MW, Forrest D 2013 Making sense with thyroid hormone- the role of T(3) in auditory development. Nat Rev Endocrinol 9:296-307.

10. Alexander EK, Kennedy GC, Baloch ZW, Cibas ES, Chudova D, Diggans J, Friedman L, Kloos RT, LiVolsi VA, Mandel SJ, Raab SS, Rosai J, Steward DL, Walsh PS, Wilde JI, Zeiger MA, Lanman RB, Haugen BR 2012 Preoperative diagnosis of benign thyroid nodules with indeterminate cytology. N Engl J Med 367:705-715.

11. Nikiforov YE, Ohori NP, Hodak SP, Carty SE, LeBeau SO, Ferris RL, Yip L, Seethala RR, Tublin ME, Stang MT, Coyne C, Johnson JT, Stewart AF, Nikiforova MN 2011 Impact of mutational testing on the diagnosis and management of patients with cytologically indeterminate thyroid nodules: a prospective analysis of 1056 FNA samples. I Clin Endocrinol Metab 96:3390-3397.

12. Gupta-Abramson V, Troxel AB, Nellore A, Puttaswamy K, Redlinger M, Ransone K, Mandel SJ, Flaherty KT, Loevner LA, O'Dwyer PJ, Brose MS 2008 Phase II trial of sorafenib in advanced thyroid cancer. J Clin Oncol 26:4714-4719.

13. Kurzrock R, Sherman SI, Ball DW, Forastiere AA, Cohen RB, Mehra R, Pfister DG, Cohen EE, Janisch L, Nauling F, Hong DS, Ng CS, Ye L, Gagel RF, Frye J, Muller T, Ratain MJ, Salgia R 2011 Activity of XL184 (Cabozantinib), an oral tyrosine kinase inhibitor, in patients with medullary thyroid cancer. J Clin Oncol 29:2660-2666.
14. Mayerl S, Visser TJ, Darras VM, Horn S, Heuer H 2012 Impact of Oatp1c1 deficiency on thyroid hormone metabolism and action in the mouse brain. Endocrinology 153:15281537.

15. Visser WE, Swagemakers SM, Ozgur Z, Schot R, Verheijen FW, van Ijcken WF, van der Spek PJ, Visser TJ 2010 Transcriptional profiling of fibroblasts from patients with mutations in MCT8 and comparative analysis with the human brain transcriptome. Hum Mol Genet 19:4189-4200.

16. Hackenmueller SA, Marchini M, Saba A, Zucchi R, Scanlan TS 2012 Biosynthesis of 3-iodothyronamine (T1AM) is dependent on the sodium-iodide symporter and thyroperoxidase but does not involve extrathyroidal metabolism of T4. Endocrinology 153:5659-5667.

17. Scanlan TS, Suchland KL, Hart ME, Chiellini G, Huang Y, Kruzich PJ, Frascarelli S, Crossley DA, Bunzow JR, Ronca-Testoni S, Lin ET, Hatton D, Zucchi R, Grandy DK 2004 3-Iodothyronamine is an endogenous and rapid-acting derivative of thyroid hormone. Nat Med 10:638-642.

Address correspondence to: Ronald J. Koenig, MD, PhD University of Michigan 5560 MSRB-2

1150 W. Medical Center Drive Ann Arbor, MI 48109-0678

E-mail: rkoenig@umich.edu 